\title{
DEVELOPING CREATIVITY: A NEW PARADIGM
}

\author{
NADZEYA NizhnEVA-KSENOFONTAVA, NATALLIA NiZHNEVA
}

\begin{abstract}
Summary. The article is devoted to the description of a new teaching paradigm, a paradigm of developing creativity in particular. Difference between a new paradigm and the old one is shown. The essence of such concepts as thinking, critical thinking, creative thinking, creativity is analyzed. Peculiarities of thinking of geniuses are described. The author presents critical thinking skills. Special attention is paid to barriers to creativity, essence of creative situations, their most distinctive features, main parameters, key principles of developing creative situations.
\end{abstract}

Key words: a new paradigm of education, a paradigm of developing creativity, thinking, critical thinking, creative thinking, creativity, barriers to creativity, creative situations

The 20th century and two decades of the 21 st century have seen an immense amount of activity in language teaching methodology. During this period many new methods in addition to traditional ones were created and they clamoured for attention. This process is caused by several factors.

It is necessary to take into consideration the situation created by shifts of paradigm, first in theories of language learning and theories of language, and then in theories of foreign language teaching.

First of all, the English language has become the language of international communication thanks to its grammatical acceptability, communicative intelligibility and social appropriateness. It is taught and learnt as global language.

There exist different approaches and methods of teaching foreign languages. Each new teaching approach, theory or method is regarded as a panacea to cure the shortcomings of previous methods. Aud Marit Simensen writes that the activities, theories, concepts etc. dominant at any time in any academic discipline are often 
said to constitute a paradigm. Thus, over time we have had a succession of various teaching methods. In academic disciplines the term is called 'shifts of paradigm' .

Aud Marit Simensen underlines that the history of foreign language teaching shows that paradigms tend to shift to some extend according to predictable cycles. Each paradigm starts with a successful period. After a certain period of time some theoretical concepts and practical tools are rejected, and then finally a new paradigm replaces the old one. A small 'revolution' or a shift of paradigm starts ${ }^{2}$.

For example, in the old paradigm of teaching, teachers' knowledge is transferred to passive learners. In a new paradigm of teaching, knowledge is actively constructed, discovered, transformed, and extended by students. Teachers' efforts are aimed at developing students' competencies and talents ${ }^{3}$.

We may find several examples of major changes in foreign language teaching theory or method due to shifts of paradigm ${ }^{4}$.

If to speak about a new paradigm of teaching foreign languages, it is necessary to emphasize the importance of developing creativity of learners.

In order to achieve this aim The Creative Platform that is considered to be a new paradigm of teaching creativity has been developed ${ }^{5}$.

The Creative Platform is a didactic approach to teach and develop creativity. C. Byrge \& S. Hansen write that on The Creative Platform creativity is defined as unlimited application of knowledge and The Creative Platform is a learning environment, where people apply their knowledge unlimited to create new knowledge constructions. According to their point of view, The Creative Platform is built on four principals: no-judgment, task-focused, parallel thinking and horizontal thinking.

\section{There are some approaches to defining thinking}

Bartlett defined thinking as interpolation (i.e. filling in gaps of information), extrapolation (i.e. going beyond the information given) and re-interpretation (i.e. rearranging information) ${ }^{6}$.

\footnotetext{
${ }^{1}$ A.M. Simensen, Teaching a foreign language. Principles and procedures, Bergen: Fagbokforlaget. 1998 .

${ }^{2}$ A.M. Simensen, Teaching a foreign language. Principles and procedures, Bergen: Fagbokforlaget. 1998 .

${ }^{3}$ D. Johnson, R.Johnson, and E. Holubec, Cooperation in the classroom, Boston: Allyn and Bacon. 1998.

${ }^{4}$ C. Byrge, and S. Hansen, The Creative Platform: a didactic for sharing and using knowledge in interdisciplinary and intercultural groups, SEFI2008 Conference Proceedings. Holland: SEFI. 2008.

${ }^{5} \mathrm{C}$. Byrge, and S. Hansen, The Creative Platform: a didactic for sharing and using knowledge in interdisciplinary and intercultural groups, SEFI2008 Conference Proceedings. Holland: SEFI. 2008.

${ }^{6}$ F. Bartlett, Thinking: an experimental and social study, London: Allen and Unwin. 1985.
} 
Dewey defined thinking as an attempt to examine and evaluate information based on certain criteria ${ }^{7}$.

Bourne, Ekstrand and Dominowski define thinking as a complex, multifaceted process that is essentially internal involving symbolic representation of events and objects initiated by some external events ${ }^{8}$.

Nickerson, Perkins and Smith looked upon thinking as a collection of skills or mental operations used by inidividuals ${ }^{9}$.

Glatthorn and Baron and Nickerson developed a list of attributes of good and poor thinkers ${ }^{10}$.

A good thinker welcomes problematic situations; uses evidence skillfully; makes judgment only after considering all points; listens to other people's views; is reflective; perseveres in searching for information.

A poor thinker prefers situations, which are more definite; prefers limited possibilities; ignores evidence; is quick to make judgment; ignores other people's views; is impulsive; gives up easily and is lazy to think further.

Linguists explore thinking of geniuses, in hopes that the reader might emulate some of their patterns. Howard Gardner began his explorations to multiple intelligences by examining thinking of geniuses. Michalko describes the following thinking patterns of geniuses ${ }^{11}$ :

Geniuses look at problems in many different ways; make their thought visible; produce many ideas; make novel combinations; force relationships; think in opposites; think metaphorically; prepare themselves for chance.

Thinking and critical thinking.

Different types of thinking are analyzed: creative thinking ${ }^{12}$, divergent thinking ${ }^{13}$ and convergent thinking ${ }^{14}$.

${ }^{7}$ J. Dewey, How we think. Boston: Heath.1963.

${ }^{8}$ L. Bourne, B. Ekstrand and R. Dominowski, The psychology of thinking, Englewood Cliffs. NJ: Prentice Hall. 1985.

${ }^{9}$ R. Nickerson, D. Perkins and E. Smith, The teaching of thinking, Hillsdale, NJ: Lawrence Erlbaum Associates. 1985.

${ }^{10} \mathrm{~J}$. Glatthorn and J. Baron, A good thinker, In A. Costa (Ed). Developing minds. Alexandria, VA: Association for Supervision and Curriculum Development. 1985.

R. Nickerson, D. Perkins and E. Smith, The teaching of thinking, Hillsdale, NJ: Lawrence Erlbaum Associates. 1985.

${ }^{11}$ M.Michalko, Thinking like a genius: eight strategies used by the supercreative, from Aristotle and Leonardo to Einstein and Edison, The Futurist 32(4): 21. 1998.

${ }^{12}$ Alice Chirico, Vlad Petre Glaveanu, Pietro Cipresso, Giuseppe Riva and Andrea Gaggioli, Awe enhances creative thinking: an experimental study, "Creativity Research Journal” 2018, Volume 30, Issue 2, 123-131.

Bob Jeffrey and Anna Craft, Teaching creatively and teaching for creativity: distinctions and relationships, "Creativity Research Journal" 2004, Volume 30, Issue 1, 77-87.

Kyung Hee Kim, The creativity crisis: the decrease in creative thinking scores on the Torrance tests of creative thinking, $b$ "Creativity Research Journal” 2011,Volume 23, Issue 4, 285-295. 
Many scientists made descriptions and classifications of both thinking and critical thinking.

In different scientific books and articles, concepts like problem-solving, decision-making, reasoning, informal logic, simple thinking and creative thinking are used as synonyms for critical thinking.

The word critical was derived from the Greek term „kritikos” which meant evaluating, judging, distinguishing, and was transferred to Latin as „criticus”, and then spread to other languages.

There exist different definitions of critical thinking. Brookfield analyses five aspects and four components of critical thinking ${ }^{15}$.

The definition of critical thinking has changed somewhat over the past decade.

William Huitt ${ }^{16}$ provides a wonderful summary of definitions. He explores perceptions of various disciplines' impact on critical thinking by looking at the influence of cognitive and behavioral psychologists, philosophers, and content specialists.

Peter Faccione introduces a five-step process of critical thinking: interpretation, analysis, evaluation, inference skills, presenting arguments, and reflection that may be used in critical analysis process ${ }^{17}$.

From the point of view of these scientists critical thinking involves evaluation of various statements and problem solving, as well as fostering creativity; stimulates the development of verbal skills, thinking, and imagination; is beneficial to encourage students to perform various reasoning operations, for example, to compare, find links between items of information, and further categorize knowledge of the world, as well as to find the most important point in a given information set.

Students should be taught how to approach a given problem. First, they must realize what they know, what they need to know, what has to be done. They must design a plan to solve it and to implement and evaluate the results ${ }^{18}$.

\section{Critical thinking skills}

Several researches stated opinions and comments on the dimensions, trends and constituent skills of critical thinking. Some of them are the following:

\footnotetext{
${ }^{13}$ Mark A. Runco and Selcuk Acar, Divergent thinking as an indicator of creative potential, "Creativity Research Journal” 2012, Volume 24, Issue 1, 66-75.

Wangbing Shen, Bernhard Hommel, Yuan Yuan, Liu Chang and Wei Zhang, Risk-taking and creativity: convergent, but not divergent thinking is better in low-risk takers, "Creativity Research Journal" 2018, Volume 30, Issue 2, 224-231.

${ }^{14}$ Arthur Cropley, In praise of convergent thinking, "Creativity Research Journal" 2006, Volume 18, Issue 3, 391-404.

${ }^{15}$ S.Brookfield, Developing critical thinkers: Challenging adults to explore alternative ways of thinking and acting, San Francisco: Jossey-Bass Publishers. 1987.

${ }^{16}$ W. Huitt, Critical thinking, Educational Psychology Interactive. 1994.

${ }^{17}$ P. Faccione, Critical thinking: what it is and why it counts, California Academic Press. 1998.

${ }^{18}$ M. Dakowska, Teaching English as a foreign language, Warszawa: Wydawnictwo Naukowe PWN. 2007. p.169.
} 
According to Decaroli, critical thinking involves seven skills, which complement each other. These skills include description, forming a hypothesis, collecting information, interpretation, generalization reasoning, evaluation and application.

The Delphi Project introduced a comprehensive description of skills covered by critical thinking. Peter Faccione ${ }^{19}$ introduces a five-step process of critical thinking: interpretation, analysis, evaluation, inference skills, presenting arguments, and reflection that may be used in critical analysis process.

Under these conditions, it is necessary to devise and use in practical work effective strategies, methods, and techniques for shaping second language teaching and the English language, in particular, for developing intellectual abilities of students.

In this connection, it is necessary to speak about the creative approach that has recently attracted increasing interest ${ }^{20}$. Creative thinking, creativity, creative field, creative sphere, mechanisms of creativity development, creative persons and motivated creative persons are analyzed. Tasks, conditions and means of creative development of a creative personality in the academic process, peculiarities, characteristics, structure, levels of creative cognitive activity are described. All these problems are very important because creativity is considered to be the basis of innovative education.

Creativity is studied across many disciplines and correspondingly there exist different approaches to defining creativity ${ }^{21}$. Accordingly, it is described as:

- a special type of sensitivity to the problems connected with lack of knowledge, identification of difficulties, processes of setting up a hypothesis;

- the creative process of producing something new;

${ }^{19}$ P. Faccione, Critical thinking: what it is and why it counts, California Academic Press. 1998.

${ }^{20}$ Marta Czerwonka and Maciej Karwowski, The order matters: asking about creative activity calibrates creative self-concept, "Creativity Research Journal" 2018, Volume 30, Issue 2, 179-186.

Haiying Long, An empirical review of research methodologies and methods in creativity studies (2003-2012), “Creativity Research Journal” 2014, Volume 26, Issue 4, 427-438.

Stephen Skalicky, A. Scott, Danielle S. Crossley, McNamara and Kasia Muldner Identifying creativity during problem solving using linguistic features, "Creativity Research Journal" 2017, Volume 29, Issue 4, 343-353.

T.Samuel, Hunter, Katrina E. Bedell and D.Michael Mumford, Climate for creativity: a quantitative review "Creativity Research Journal" 2007, Volume 19, Issue 1, 69-90.

Sandi Mann and Rebekah Cadman, Does being bored make us more creative? "Creativity Research Journal" 2014, Volume 26, Issue 2, 165-173.

${ }^{21}$ Todd Kettler, Kristen N. Lamb, Amy Willerson and Dianna R. Mullet, Teachers' perceptions of creativity in the classroom, "Creativity Research Journal" 2018, Volume 30, Issue 2, 164-171.

Mark A. Runco, The standard definition of creativity, "Creativity Research Journal" 2012, Volume 24, Issue 1, 92-96.

Robert J. Sternberg, The nature of creativity, "Creativity Research Journal" 2006, Volume 18, Issue 1, 87-98. 
- "the act of turning new and imaginative ideas into reality. Creativity involves two processes: thinking, then producing, 22 ;

- integrated quality of a person.

Michael Mumford ${ }^{23}$ suggested: "Over the course of the last decade, however, we seem to have reached a general agreement that creativity involves the production of novel, useful products".

Rollo May claims:

„Creativity is the process of bringing something new into being... creativity requires passion and commitment. Out of the creative act are born symbols and myths. It brings to our awareness what was previously hidden and points to new life. The experience is one of heightened consciousness-ecstasy" ${ }^{\prime 2}$.

Leonard and Swap believe ,the creative process...consists of 1) preparation, 2) innovation opportunity, 3) divergence or the generation of options, 4) incubation, and 5) convergences or the selection of options"25. Here we combine divergence, convergence and innovation.

Todd I. Lubart and Robert J. Sternberg describe creativity in the following way:

„A product is creative when it is (a) novel and (b) appropriate. A novel product is original not predictable. The bigger the concept, and the more the product stimulate further work and ideas, the more the product is creative" ${ }^{\text {"26 }}$.

Albert, as quoted in Feldhusen and Goh, proposes six guiding ideas to „grasp the essence of creativity": creativity is expressed through decisions, not products; knowledge of self and of one's world is the medium of creative behavior; creative behavior is highly intentional; creativeness and personal identity are emergent; creative behavior and creativeness and personal identity are mutually dependent; creative behavior engages individuals at the personal level of their identities and abilities $^{27}$.

According to Smith, Paradice et al. there are four behaviors that prepare the mind for creativity: 1) learn something new every day, 2) seek out constructive criti-

\footnotetext{
${ }^{22}$ L. Naiman, What is creativity? 2010. www.creativityatwork.com (Date of access: 25 September, 2011).

${ }^{23}$ M.D. Mumford, Where have we been, where are we going? Taking stock in creativity research, "Creativity Research Journal", 2003. 15, 110.

${ }^{24} \mathrm{R}$. May, 1994. The courage to create. http://www.allgraphicdesign.com/phpBB2/viewtopic.php? $\mathrm{f}=6 \& \mathrm{p}=157407$ (Date of access: 25 September, 2011).

${ }^{25}$ E. P. Kelly, When sparks fly: igniting creativity in groups, The Academy of Management Executive 2000. 14(1): 157.

${ }^{26}$ T. I. Lubart and R. J. Sternberg, Defying the crowd: cultivating creativity in a culture of conformity publisher, 1995. http://www.creativityatwork.com/articlesContent/whatis.htm (Date of access: 25 September, 2011).

${ }^{27}$ J.F. Feldhusen and B.E. Goh, Assessing and accessing creativity: an integrative review of theory, research, and development, "Creativity Research Journal", 1995. 8 (3): 231, 17p.
} 
cism, 3) incubate, or leave a problem alone for a while to allow the brain to work on it, and 4) put knowledge to work ${ }^{28}$.

Thomas describes barriers to creativity. His list is based on the work of Alexander Hiam, and includes nine barriers: failures to ask questions; to record ideas; to revisit ideas; to express ideas; to think in new ways; to wish for more; to try being creative; to keep trying; to tolerate creative behavior ${ }^{29}$.

Bellis also writes about Scott Isaksen and Donald Treffinger's creative problem solving model. Jean Marrapodi in his paper "Critical thinking and creativity an overview and comparison of the theories" describes their basic course that has six stages: mess finding, data finding, problem finding, idea finding, solution finding and acceptance finding. According to them:

Creative thinking and critical thinking is described in the following way ${ }^{30}$ :

\begin{tabular}{|l|l|}
\hline \multicolumn{1}{|c|}{$\begin{array}{c}\text { Creative thinking } \\
\text { Students: }\end{array}$} & \multicolumn{1}{c|}{$\begin{array}{c}\text { Critical thinking } \\
\text { Students: }\end{array}$} \\
\hline $\begin{array}{l}\text { make and communicate connections to think of } \\
\text { many possibilities }\end{array}$ & $\begin{array}{l}\text { analyze and develop possibilities to compare and } \\
\text { contrast many ideas }\end{array}$ \\
\hline $\begin{array}{l}\text { think and experience in various ways and use } \\
\text { different points of view }\end{array}$ & refine ideas \\
\hline think of new and unusual possibilities & make effective decisions and judgments \\
\hline guide in generating and selecting alternatives & provide a sound foundation for effective action \\
\hline
\end{tabular}

One of the most effective techniques of develop creativity of students is a creative situation.

The most distinctive feature of creative situations is its function to create situations for encouraging and developing creative activities of students that do not limit their intellectual activity. In general, a creative situation may be defined as a complex of external conditions and diverse forms of individual and teamwork that spur students on to intellectual creative activity, promote the development of creative motivation.

Main parameters of creative situations are cognitive value, purposefulness, context, motives and aims, exchange of new information, encouragement of intellectual activity of students.

Key principles of developing creative situations can be described in the following way: systematic and founded complication, encouragement and development of creative, cognitive links of intellectual activity of students, their intellectual creative abilities.

\footnotetext{
${ }^{28}$ D.K. Smith, D.B. Paradice, et al. Prepare your mind for creativity, Association for Computing Machinery. Communications of the ACM. 2000. 43(7): 110.

${ }^{29}$ J. Thomas, Nine barriers to thinking creatively, Women in Business. 1999. 51(1): 14.

${ }^{30} \mathrm{M}$. Bellis, Critical thinking skills - creative thinking: Calvin Taylor's model of creative thinking and critical thinking, M. Bellis. 2003.
} 
Creative situations may be classified according to:

- the means of solving problems or contradictions;

- character of cognitive activity performed;

- level of difficulty of contradictions.

Types of contradictions:

- contradictions of informative and cognitive character;

- contradictions in argumentation;

- contradictions in information: inaccurate, insufficient, unsound, disputable etc;

- contradictions between arguments and conclusions, the premise and the conclusion; cause and effect etc.

Thus, creative situations can provide the necessary conditions for developing creative and heuristic abilities of learners that include abilities:

- to generate ideas, use analogy;

- to deconstruct contradictions, problems;

- logical, critical, creative imagination;

- flexibility of thinking;

- creative thinking;

- transference of knowledge, skills and habits.

\section{Conclusion}

Teachers in the classroom must be prepared to experience one or may be two professional 'revolutions' or major shifts during their career.

Whatever strategies, methods or techniques are used for teaching our students for developing their specific language skills and habits, intellectual abilities, linguistic competence, our students will each learn in their own way depending on their individual abilities, and they can learn better, if we apply not only new knowledge that is available to us but also our creativity. Moreover, English full of mysteries and secrets is in a state of constant change. The creative aspect of language knowledge and language teaching is obvious. Ralph Waldo Emerson said that „The English language is the sea which receives tributaries from every region under heaven"31.

\section{References}

Bartlett, F.1985. Thinking: an experimental and social study. London: Allen and Unwin.

Bellis, M. 2003. Critical thinking skills - creative thinking: Calvin Taylor's model of creative thinking and critical thinking. M. Bellis.

\footnotetext{
${ }^{31}$ R. McCrum, W. Cran and R. MacNeil, The story of English, 1986. New York, N.Y: Elisabeth Sifton.
} 
Bourne, L., Ekstrand, B. and R. Dominowski. 1985. The psychology of thinking. Englewood Cliffs, NJ: Prentice Hall.

Brookfield, S. 1987. Developing critical thinkers: challenging adults to explore alternative ways of thinking and acting. San Francisco: Jossey-Bass Publishers.

Byrge, C. and S. Hansen. 2008. The creative platform: a didactic for sharing and using knowledge in interdisciplinary and intercultural groups. SEFI 2008 Conference Proceedings. Holland: SEFI.

Carson, S.H, Peterson, J.B. and D.M. Higgins. 2005. "Reliability, validity, and factor structure of the creative achievement questionnaire". Creativity Research Journal 17 (1). 37-50.

Chirico, A., Glaveanu, V.P., Cipresso, P., Riva, G. and A. Gaggiol. 2018. "Awe enhances creative thinking: an experimental study". Creativity Research Journal 30 (2). 123-131.

Cropley, A. 2006. "In praise of convergent thinking". Creativity Research Journal 18 (3). 391-404.

Czerwonka, M. and M. Karwowski. 2018. „The order matters: asking about creative activity calibrates creative self-concept". Creativity Research Journal 30 (2). 179 -186.

Dakowska, M. 2007. Teaching English as a foreign language. Warszawa: Wydawnictwo Naukowe PWN. 169.

Dewey, J. 1963. How we think. Boston: Heath.

Faccione, P. 1998. Critical thinking: what it is and why it counts. Hermosa Beach, CA: California Academic Press.

Feldhusen, J.F. and B.E. Goh. 1995. "Assessing and accessing creativity: an integrative review of theory, research, and development". Creativity Research Journal 8 (3). 231, 17.

Glatthorn, J. and J.A. Baron. 1985. "Good thinker". In: Costa, A. (ed). Developing minds. Alexandria, VA: Association for Supervision and Curriculum Development. 49-53.

Hunter, S.T., Bedell, K.E. and M.D. Mumford. 2007. "Climate for creativity: a quantitative review". Creativity Research Journal 19 (1). 69-90.

Jeffrey, B. and A. Craft. 2004. "Teaching creatively and teaching for creativity: distinctions and relationships". Creativity Research Journal 30 (1). 77-87.

Johnson, D., Johnson, R. and E. Holubec. 1998. Cooperation in the classroom. Boston: Allyn and Bacon.

Kasirer, A. and N. Mashal. 2018. "Fluency or similarities? Cognitive abilities that contribute to creative metaphor generation". Creativity Research Journal 30 (2). 205-211.

Kettler, T., Lamb, K.N., Willerson, A. and D.R. Mullet. 2018. "Teachers' perceptions of creativity in the classroom". Creativity Research Journal 30 (2). 164-171.

Kim, K.H. 2011. "The creativity crisis: the decrease in creative thinking scores on the torrance tests of creative thinking". Creativity Research Journal 23 (4). 285-295.

Long, H. 2014. "An empirical review of research methodologies and methods in creativity studies (2003-2012)". Creativity Research Journal 26 (4). 427-438.

Lubart, T.I. and R.J. Sternberg. „Defying the crowd: cultivating creativity in a culture of conformity”. Publisher. http://www.creativityatwork.com/articlesContent/whatis.htm (Date of access: 25 September, 2011).

Mann, S. and R. Cadman. 2014. "Does being bored make us more creative?". Creativity Research Journal 26 (2). 165-173.

Michalko, M. 1998. "Thinking like a genius: eight strategies used by the supercreative, from Aristotle and Leonardo to Einstein and Edison". The Futurist 32 (4). 21.

Mumford, M.D. 2003. "Where have we been where are we going? Taking stock in creativity research". Creativity Research Journal 15 (2). 107-120.

Naiman, L. "What is creativity?" www.creativityatwork.com (Date of access: 25 September, 2011).

Nickerson, R., Perkins, D. and E. Smith. 1985. The teaching of thinking, Hillsdale, NJ: Lawrence Erlbaum Associates. 
Runco, M.A. and S. Acar. 2012. "Divergent thinking as an indicator of creative potential". Creativity Research Journal 24 (1). 66-75.

Runco, M.A. 2012. "The standard definition of creativity". Creativity Research Journal 24 (1). 92-96.

Scott, G., Leritz, L.E. and M.D. Mumford. 2004. "The effectiveness of creativity training: a quantitative review”. Creativity Research Journal 16 (4). 361-388.

Shen, W., Hommel, B., Yuan, Y., Chang, L. and W. Zhang. 2018. "Risk-taking and creativity: convergent, but not divergent thinking is better in low-risk takers". Creativity Research Journal 30 (2). 224-231.

Simensen A.M., Teaching a foreign language. Principles and procedures. Bergen: Fagbokforlaget. 1998.

Skalicky, S., Crossley, S.A., McNamara, D.S. and K. Muldner. 2017. "Identifying creativity during problem solving using linguistic features". Creativity Research Journal 29 (4). 343-353.

Smith, D.K., Paradice, D.B. and S.M. Smith. 2000. "Prepare your mind for creativity association for computing machinery". Communications of the ACM 43 (7). 110-116.

Sternberg, R.J. 2006. "The nature of creativity”. Creativity Research Journal 18 (1). 87-98.

Thomas, J. 1999. "Nine barriers to thinking creatively". Women in Business 51 (1). 14.

Zaniewski, J., Nizhneva, N. and N. Nizhneva-Ksenofontava. 2015. "Kreatywność w glottodydaktyce filologów”. In: Puppel, S. (red.) MOTEK. Motywy ekolingwistyczne: w stronę ekoglottodydaktyki. Materiały z Konferencji zorganizowanej przez Katedrę Ekokomunikacji Uniwersytetu im. Adama Mickiewicza w Poznaniu w dniach 10-11 września 2014 roku. Poznań: Katedra Ekokomunikacji UAM. 219-226.

Nizhneva-Ksenofontava, N.L. 2007. Konstruktor kreatywnoj licznosti. Uczebnoje posobije. Minsk: RIWSZ. 